\title{
Lesões ruminais causadas pela ingestão de metais traços
}

Natali Regina Schllemer, Angela Maria Reck, Bruna Artner, Alessandra Coelho Mayer, Desirre Pontarollo, Jayme Augusto Peres, Heloisa Godoi Bertagnon

Universidade Estadual do Centro-Oeste (UNICENTRO), Guarapuava, PR, Brasil

*Autor correspondente

e-mail: hgodoi@usp.br

\section{Resumo}

Os metais traços estão contidos em uma série de produtos, como herbicidas, e quando utilizados se acumulam em recursos naturais como água, solo e plantas, podendo contaminar os animais. Uma vez que herbívoros, particularmente os ruminantes, ingerem estas fontes contaminadas, metais traços como níquel e chumbo chegam ao trato gastrointestinal, comprometendo as mucosas e a absorção de ácidos graxos de cadeia curta, o que interfere no desempenho animal e pode favorecer a ocorrência de enfermidades como distúrbios circulatórios e/ou timpanismo. Sabe-se que estes metais traços se acumulam principalmente no rúmen, causando alterações do desenvolvimento celular como atrofia do epitélio ruminal, apoptose e até mesmo displasias celulares, o que interfere com o metabolismo celular e pode resultar em alterações do tamanho das vilosidades ruminais. Este trabalho teve como objetivo analisar se a intensidade da atrofia do epitélio ruminal é proporcional aos teores de chumbo e níquel encontrados no rúmen de bovinos. Para tanto, 16 bovinos da raça Angus X Nelore (350 $\pm 50 \mathrm{~kg}, 11 \pm 2$ meses de idade) foram confinados durante 116 dias, recebendo uma dieta constituída por uma mistura de $80 \%$ de grãos de milho inteiros e $20 \%$ de núcleo proteico-vitamínico-mineral, ad libitum. No dia do abate, amostras do rúmen foram coletadas, sendo uma alíquota de cada animal armazenada em solução de formalina tamponada a 10\% para, posteriormente, ser preparada para análise histopatológica. As lesões ruminais receberam escores (ER) de 0 a 3 de acordo com o grau de atrofia, sendo 0 a ausência de lesão ruminal e graus de 1 a 3 de acordo com a magnitude da apoptose de células epiteliais em vilosidades ruminais, neovascularização e metaplasia, sendo o grau 3 o mais severo. A outra alíquota de amostras ruminais foram refrigeradas a $4^{\circ} \mathrm{C}$, para posterior mensuração de níquel (Ni) e chumbo $(\mathrm{Pb})$ pela técnica de espectrofotometria de absorção atômica. As lesões histopatológicas foram correlacionadas aos teores de níquel e chumbo pela correlação de Pearson. Foi encontrada apenas correlação positiva e forte entre níquel e ER $(\mathrm{r}=0,74, \mathrm{P}=0,0009)$. Tais achados indicam que possivelmente o níquel 
comprometeu a proliferação do epitélio celular, que deveria substituir as células em apoptose, levando a uma hipotrofia epitelial. Juntamente, observou-se neovascularização e metaplasia, indicando que as células epiteliais originais foram substituídas por células menos diferenciadas, com maior resistência, porém de menor função biológica, demonstrando uma fase inicial de processo inflamatório. Não se encontrou correlação entre chumbo e ER (chumbo e ER r = 0,12, P = 0,66). Desta maneira, conclui-se que a intensidade das lesões em epitélio ruminal foi proporcional aos teores de níquel encontrados em rúmen. 